\title{
ASSESSMENT OF GENETIC DIVERSITY AND POPULATION STRUCTURE OF SOME SOFT AND HARD WHEAT VARIETIES BASED ON SSR MARKER
}

\author{
Yousif M. Fattah $^{\text {a }}$, Nergiz N. Tayib ${ }^{\text {a }}$ \\ ${ }^{a}$ Dept. Of Biology, Faculty of Science, University of Zakho, Kurdistan Region- Iraq \\ (yousif.fattah@uoz.edu.krd; nergizi8892@gmail.com)
}

\begin{abstract}
:
Wheat (Triticum spp.) is one of the most important cereal crops in Iraq and the world. It includes many species and varieties. The two major cultivated species of wheat are, durum wheat (Tritium durum Desf.) which is tetraploid $(2 \mathrm{n}=28)$ and the common wheat (Triticum aestivum $\mathrm{L}$.) which is hexaploid $(2 \mathrm{n}=42)$. Ten wheat varieties from both species were examined using ten Simple sequence repeat (SSR) markers (WMC17, WMC20, WMC21, WMC24, WMC25, WMC48, WMC50, WMC283, Xgwm11 and Xgwm626). Various genetic parameters were calculated using Power Marker V3.25 software. A total of 156 alleles were detected in both species. The gene diversity in wheat varieties from both species collectively varied from 0.85 to 1.00 , which indicates considerable genetic diversity in the examined varieties. All markers used in this study were highly informative and the polymorphic information content (PIC) values were higher than 0.50 in all loci. Hence all markers are considered useful for genetic diversity studies in wheat's populations. The dendrogram separated the populations into two main clades and many subgroups. Azadi variety was simplicifolious. This study confirms the discriminating power of SSR typing and its usefulness for comparison within hard and soft wheat populations.
\end{abstract}

KEYWORDS: Triticum sp., hard and soft wheat, SSR markers, genetic diversity, population genetics.

\section{INTRODUCTION}

Wheat is a species of agricultural importance as cereal grains in most countries around the world, as well as in Iraq (Slim et al., 2019). It is an annual self-pollinating plant belonging to the family Poaceae (grasses) and genus Triticum (Shewry, 2009). The two most cultivated species of wheat are durum (Triticum turgidum Desf.) subsp. durum, genome $\mathrm{AABB}$, which is tetraploid $(2 \mathrm{n}=4 \mathrm{x}=28)$ with 14 pairs of chromosomes, and the soft wheat (Triticum aestivum L.), genome AABBDD, which is hexaploid $(2 \mathrm{n}=6 \mathrm{x}=42))$ with 21 pairs of chromosomes (Kara and Knaouni, 2017). Wheat provides much of food source to human. The global demand for wheat yields is growing parallel to the steady increasing in the human population (Allen et al., 2017). In addition to significant agronomic features, breeders around the world are working for increased grain yield with better quality (Desheva and Kyosev, 2015). The selection of diverse genotypes is an important step for molecular breeding of wheat (Raj et al., 2017). Microsatellites are an effective tool in diversity studies for identification of the degree of genetic similarity (Salem et al., 2015). They are independent of environmental conditions under which phenotypic studies are carried out. SSRs are tandem repeat motifs composed of one to six nucleotides. They are suitable for detecting allele frequency within the population and for assessing population structure (Kumar et al., 2016). It has been considered as one of the most effective molecular markers for genetic discrimination within interspecific or intraspecific species. SSR markers have major applications as highly variable and multi-allelic PCR based genetic markers. They are abundant and scattered all over the eukaryotic genomes with a high polymorphism rate (Kesawat and Kumar, 2009). Different studies have reported the use of SSRs to reveal polymorphisms in the wheat population (Khan et al. 2015;
Zarei., et al., 2016; Ya Narantsetseg et al., 2017; Salehi et al 2018; Yadav and Chand, 2018; El-Fiki and Adly, 2019). The results of these investigations indicated that wheat populations had high genetic diversity that can be used in wheat conservation and breeding programs, as well most SSR markers used showed a high level of polymorphism in wheat. This study was conducted to evaluate genetic diversity and population structures of both soft and hard wheat cultivars using ten polymorphic SSR markers.

\section{MATERIALS AND METHODS}

\subsection{Plant materials collection}

Seeds of 10 released varieties have been collected from the Agricultural Research Center of Duhok / Kurdistan Region of Iraq. Five of them were hard wheat varieties; Icarasha, Acsad, Secondroue, Simeto, Berghouata and the other were soft wheat varieties; Noor, Azadi, Tamoz2, Sham4, Adana99. These varieties have been released either by ICARDA or Acsad international research centers. The grains collected from each plant were grown in a separate plastic culture plate filled with a mixture of soil and peat moss during December 2018, at Biology Department Lab / University of Zakho. For genomic DNA extraction, fresh leaf samples were collected from 21 days old seedlings. Healthy leaves were chopped with sterilized scissors and washed in distilled water then with ethanol $70 \%$ for two minute to remove any sources of foreign DNA. Leaf samples were ground in the presence of liquid nitrogen, using mortar and pistil to make a fine powder and then the powder transferred to $1.5 \mathrm{ml}$ Eppendorf tubes for DNA extraction. 


\subsection{DNA extraction and microsatellites analysis}

Total genomic DNA was extracted from ground leaves using DNA extraction kit (4001Korea) according to the instructions provided by the supplier company (GeNetBio). Ten polymorphic SSR microsatellites (Table1) were used in screening all varieties. All extracted DNA samples were checked by Nanodrop instrument for their quality and purity.

\subsection{PCR amplification}

Reaction was performed using PCR Eppendorf tubes by mixing $12.5 \mu \mathrm{l}$ of $2 \mathrm{x}$ master mix, $1 \mu \mathrm{l}$ from each forward and reverse primer and 2-3 $\mu \mathrm{l}$ of DNA, the volume was made up to $25 \mu \mathrm{l}$ by deionized distilled water. The thermocycling program was optimized at initial denaturation at $94^{\circ} \mathrm{C}$ for 4 minutes followed by 35 cycles of $95^{\circ} \mathrm{C}$ for 1 minute, 1 minute at annealing temperature $\left(52\right.$ to $64^{\circ} \mathrm{C}$ gradient cycle), 1 minute at $72^{\circ} \mathrm{C}$ for extension followed by one cycle of final extension at $72^{\circ} \mathrm{C}$ for $5 \mathrm{~min}$ and hold at $4^{\circ} \mathrm{C}$. The PCR products were run on $1 \%$ agarose gel which was prepared by dissolving $1 \mathrm{~g}$ of agarose in 100

Table 1. Locus name, motif repeats, sequences, chromosome location and annealing temperature of 10 SSR microsatellite markers used in this study supplied by Macrogen Company / South Korea (Kara et al., 2017; Röder et al., 1998)

\begin{tabular}{|c|c|c|c|c|}
\hline Locus & Motif & Sequences & $\begin{array}{c}\text { Location on } \\
\text { Chromosomes }\end{array}$ & $\begin{array}{c}\text { Annealing } \\
\text { Temp. }\end{array}$ \\
\hline WMC 17 & $(\mathrm{CA})$ & $\begin{array}{c}\text { F-ACCTGCAAGAAATTAGGAAC } \\
\text { R-CTAGTGTTTCAAATATGTCGA }\end{array}$ & $7 \mathrm{7A-7B}$ & $54 \mathrm{C}^{0}$ \\
\hline WMC 20 & $(\mathrm{CA})$ & $\begin{array}{c}\text { F-TTAAAAACACGCGGATCTTCTC } \\
\text { R-GTACTCACATATTTCTCGGTCT }\end{array}$ & $1 \mathrm{~A}$ & $54 \mathrm{C}^{0}$ \\
\hline WMC 21 & $(\mathrm{GA}) 37$ & $\begin{array}{c}\text { F-CGCTGCCGTGTAACTCAAAATC } \\
\text { R-AGTTAATTGGGCGCTCCAAGAA }\end{array}$ & - & $55 \mathrm{C}^{0}$ \\
\hline WMC 24 & $(\mathrm{GT}) 28$ & $\begin{array}{c}\text { F-GTGAGCAATTTTGATTATACTG } \\
\text { R-TACCCTGATGCTGTAATATGTG }\end{array}$ & $1 \mathrm{~A}$ & $52 \mathrm{C}^{0}$ \\
\hline WMC 25 & $(\mathrm{GT}) 26$ & $\begin{array}{c}\text { F-TCTGGCCAGGATCAATATTACT } \\
\text { R-TAAGATACATAGATCCAACACC }\end{array}$ & $2 \mathrm{~B}$ & $52 \mathrm{C}^{0}$ \\
\hline WMC 48 & $(\mathrm{GA}) 9$ & $\begin{array}{c}\text { F-GAGGGTTCTGAAATGTTTTGCC } \\
\text { R-ACGTGCTAGGGAGGTATCTTGC }\end{array}$ & $4 \mathrm{~B}$ & $64 \mathrm{C}^{0}$ \\
\hline WMC 50 & $(\mathrm{GT}) 10(\mathrm{GT}) 16$ & $\begin{array}{c}\text { F- CTGCCGTCAGGCCAGGCTCACA } \\
\text { R-CAACCAGCTAGCTGCCGCCGAA }\end{array}$ & $3 \mathrm{~A}$ & $60 \mathrm{C}^{0}$ \\
\hline WMC 283 & $(\mathrm{CA}) 19(\mathrm{CA}) 8$ & $\begin{array}{c}\text { F-CGTTGGCTGGGTTATATCATCT } \\
\text { R- GACCCGCGTGTAAGTGATAGGA }\end{array}$ & $4 \mathrm{~A}$ & $57 \mathrm{C}^{0}$ \\
\hline Xgwm 11 & $\begin{array}{c}\text { (TA) } 6 \text { CATA } \\
(\mathrm{CA}) 19(\mathrm{TA}) 6\end{array}$ & $\begin{array}{c}\text { F-GGATAGTCAGACAATTCTTGTG } \\
\text { R-GTGAATTGTGTCTTGTATGCTTCC }\end{array}$ & $1 \mathrm{~B}$ & $57 \mathrm{C}^{0}$ \\
\hline Xgwm 626 & $(\mathrm{CT}) 5(\mathrm{GT}) 13$ & $\begin{array}{c}\text { F- GATCTAAAATGTTATTTCTCTC } \\
\text { R- TGACTATCAGCTAAACGTGT }\end{array}$ & $6 \mathrm{~B}$ & $52 \mathrm{C}^{0}$ \\
\hline
\end{tabular}

$\mathrm{ml}$ of $1 \mathrm{X}$ TBE buffer, the PH of the buffer was adjusted to 8 , for 5 min with 45 volts then for 60 min with 80 volts. Then the PCR products electrophoresed on $8 \%$ polyacrylamide gel (PAGE). The polyacrylamide gel was prepared by adding $6.650 \mathrm{ml}$ of acrylamide solution and $5 \mathrm{ml}$ of $5 \mathrm{X}$ TBE to $13.150 \mathrm{ml}$ of deionized water. Then $350 \mu \mathrm{l}$ of $10 \%$ ammonium persulfate with $20 \mu \mathrm{l}$ of TEMED was added. The gel was run for 30 min with 65 volts, then for another 40 min on 120 volts until the dark blue dye run off the bottom. The bands were measured to $25 \mathrm{bp}$ ladder. The amplified DNA bands were visualized by silver staining according to a protocol by Bassam and Gresshoff (2007).

\subsection{Data analysis}

The resulting data was analyzed using power marker V3.25 software. The genetic relationship parameters calculated according to Nei's (1973 and 1987) statistics. The similarity matrix was used to construct the dendrogram using the unweighted pair group method arithmetic averages (UPGMA) procedure (Sokal and Michener, 1958). The tree viewed by using the TREEVEIW (version 1.66) software.

\section{RESULTS}

Ten used SSR markers were highly polymorphic with amplification bands in all 10 varieties of wheat. Figure 1 shows an example of a polyacrylamide gel profile generated using WMC24 primer.

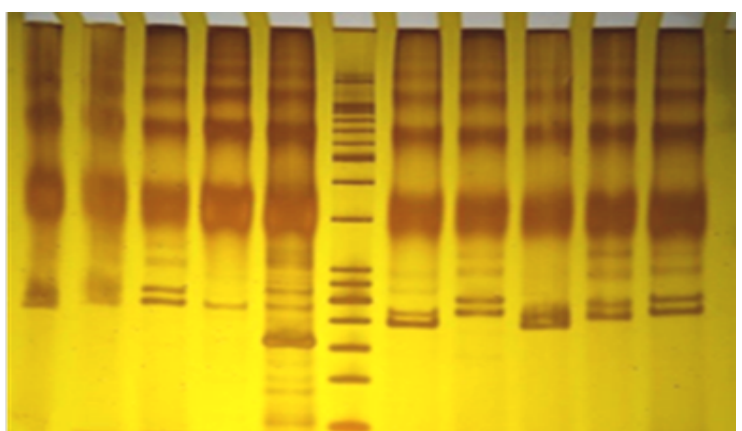

Figure 1. polyacrylamide gel profile in two populations of wheat Triticum aestivum L. and Triticum durum Desf. using (WMC24) primer. L: Represents the DNA ladder, V1: Icrasha; V2: Acsad; V3: Noor; V4: Azadi; V5: Secondroue; L: Ladder V6:Simeto; V7: Tamoz 2; V8: Berghouata; V9: Sham4; V10: Adana 99

\subsection{Population structure of soft wheat varieties (Triticum} aestivum $\mathrm{L}$.)

Allele sizes of soft wheat varieties (Table 2) in different loci ranged from 74 to $226 \mathrm{bp}$ in different loci. Table 3 shows the genetic diversity in the five soft wheat varieties based on 10 SSR markers. Allele frequency ranged from 0.10 for WMC24 
and Xgwm626 loci to 0.38 at WMC20 locus with a mean of 0.19 . In this species, a total number of 75 alleles with an average of 7.5 have been detected. WMC24 and Xgwm626 loci scored the highest number of alleles (10) while the least score of five was detected at WMC21 and WMC25 loci. To obtain a reliable data analysis, the value of the availability which is the number of observed alleles per number of individuals sampled was calculated. This value was found to be high in this population with an average of 0.96 .

This average indicated that the number of null alleles (not amplified) was only in two samples (Azadi variety at Xgwm11 and Tamoz2 at WMC20 loci). Heterozygosity at a locus is an indicator of the genetic variability. Observed heterozygosity (Ho) and the genetic diversity or expected heterozygosity (He) were calculated and found that the expected heterozygosity $(\mathrm{He})$ in this group ranged from 0.78 in WMC20 locus to 0.90 in WMC24 and Xgwm626 loci with an average of 0.85 . The Ho was ranged between 0.4 in $\mathrm{WMC} 17$ locus to 1.0 in Xgwm626, Xgwm11 and WMC24 loci, with average of 0.66. The polymorphic information content (PIC) values for overall genetic variability also calculated for all primers (Tables 3 ). The highest PIC value of 0.89 observed in Xgwm626 and WMC24 loci and the lowest value of 0.75 in WMC20 with an average of 0.83 for all loci.

Table 2. Shows allele's size in soft wheat varieties (Triticum aestivum L.)

\begin{tabular}{|c|c|c|c|c|c|}
\hline Primers & Noor & Azadi & Tamoz 2 & Sham4 & Adana 99 \\
\hline WMC 17 & $185 / 205$ & $182 / 182$ & $193 / 203$ & $206 / 206$ & $212 / 212$ \\
\hline WMC 20 & $112 / 127$ & $112 / 112$ & $? / ?$ & $117 / 132$ & $118 / 133$ \\
\hline WMC 21 & $74 / 74$ & $76 / 76$ & $75 / 75$ & $81 / 81$ & $84 / 84$ \\
\hline WMC 24 & $149 / 164$ & $134 / 144$ & $136 / 151$ & $130 / 142$ & $135 / 150$ \\
\hline WMC 25 & $119 / 119$ & $121 / 121$ & $142 / 142$ & $143 / 143$ & $138 / 138$ \\
\hline WMC 48 & $116 / 116$ & $118 / 134$ & $115 / 133$ & $115 / 131$ & $118 / 134$ \\
\hline WMC 50 & $95 / 95$ & $96 / 108$ & $107 / 118$ & $110 / 123$ & $113 / 125$ \\
\hline WMC 283 & $86 / 98$ & $88 / 88$ & $93 / 102$ & $92 / 106$ & $97 / 110$ \\
\hline Xgwm 11 & $212 / 226$ & $? / ?$ & $196 / 214$ & $197 / 218$ & $200 / 220$ \\
\hline Xgwm 626 & $115 / 130$ & $93 / 105$ & $129 / 142$ & $134 / 148$ & $135 / 145$ \\
\hline
\end{tabular}

Table 3. Shows the genetic diversity in five soft wheat varieties based on 10 SSR markers

\begin{tabular}{|c|c|c|c|c|c|c|c|}
\hline Marker & $\begin{array}{c}\text { Allele } \\
\text { Frequency }\end{array}$ & $\begin{array}{c}\text { Genotype } \\
\text { Number }\end{array}$ & $\begin{array}{c}\text { Allele } \\
\text { Number }\end{array}$ & Ava & He & Ho & PIC \\
\hline WMC17 & 0.20 & 5.00 & 7.00 & 1.00 & 0.84 & 0.40 & 0.82 \\
\hline WMC20 & 0.38 & 4.00 & 6.00 & 0.80 & 0.78 & 0.75 & 0.75 \\
\hline WMC21 & 0.20 & 5.00 & 5.00 & 1.00 & 0.80 & 0.00 & 0.77 \\
\hline WMC24 & 0.10 & 5.00 & 10.00 & 1.00 & 0.90 & 1.00 & 0.89 \\
\hline WMC25 & 0.20 & 5.00 & 5.00 & 1.00 & 0.80 & 0.00 & 0.77 \\
\hline WMC48 & 0.20 & 4.00 & 6.00 & 1.00 & 0.82 & 0.80 & 0.79 \\
\hline WMC50 & 0.20 & 5.00 & 9.00 & 1.00 & 0.88 & 0.80 & 0.87 \\
\hline WMC283 & 0.20 & 5.00 & 9.00 & 1.00 & 0.88 & 0.80 & 0.87 \\
\hline Xgwm11 & 0.13 & 4.00 & 8.00 & 0.80 & 0.88 & 1.00 & 0.86 \\
\hline Xgwm626 & 0.10 & 5.00 & 10.00 & 1.00 & 0.90 & 1.00 & 0.89 \\
\hline Mean & $\mathbf{0 . 1 9}$ & $\mathbf{4 . 7 0}$ & $\mathbf{7 . 5 0}$ & $\mathbf{0 . 9 6}$ & $\mathbf{0 . 8 5}$ & $\mathbf{0 . 6 6}$ & $\mathbf{0 . 8 3}$ \\
\hline
\end{tabular}

3.1.1 Genetic relationships between soft wheat varieties: Gene1 distances were calculated for these soft wheat varieties to estimate $t$ extent of their divergence. Table (4) shows the lowest genetic distan (0.610) was found between Tamoz 2 and Sham 4 and the hight genetic distance (0.722) was found between Azadi variety and Shan variety. The average genetic distance among the varieties was equal 0.668 The results of the phylogenetic dendrogram based on the genet analysis of distance matrix is displayed in Figure 2. The dendrogra separated the five soft wheat varieties into two main groups. The fit group consists of Azadi variety. The second group was divided in three sub accessions consists of the rest varieties. The hight similarity value was observed between Tamoz 2 and sham 4 varieti while the highest distance was between Azadi and Sham4 varietis Azadi variety was different from the rest varieties and formed a uniqtigure 2. Dendrogram for five soft wheat varieties showing the genetic leave.

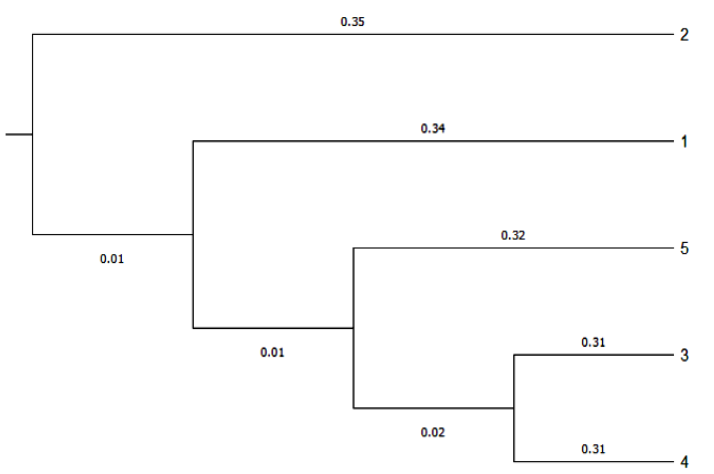

similarity derived from a UPGMA cluster analysis 


\subsection{Population structure of hard wheat varieties (Triticum} durum Desf.)

Allele sizes of hard wheat varieties (Table5) at different loci ranged between $73 \mathrm{bp}$ to $234 \mathrm{bp}$. The genetic diversity in the five hard wheat varieties is shown in Table 6 . Allele frequency ranged from 0.10 for WMC25, WMC48 and Xgwm626 loci to
0.40 for WMC21 locus with an overall mean of 0.21 . The total number of the detected alleles was 81 and the average value was 8.1. The highest number of alleles (10) was scored at WMC25, WMC48 and Xgwm626 loci, while the lowest score of four alleles was at WMC21 locus.

Table 4. Shows the genetic distance for the five soft wheat varieties based on 10 SSR microsatellite markers, the varieties are: 1-Noor, 2-Azadi, 3-Tamoz2, 4-Sham4, 5-Adana99

\begin{tabular}{|c|c|c|c|c|c|}
\hline Primers & Icrasha & Acsad & Secondroue & Simeto & Berghouata \\
\hline WMC 17 & $200 / 214$ & $189 / 198$ & $180 / 180$ & $175 / 175$ & $198 / 198$ \\
\hline WMC 20 & $117 / 131$ & $112 / 125$ & $112 / 127$ & $113 / 128$ & $113 / 127$ \\
\hline WMC 21 & $75 / 75$ & $73 / 73$ & $75 / 75$ & $74 / 74$ & $78 / 78$ \\
\hline WMC 24 & $146 / 160$ & $152 / 152$ & $103 / 118$ & $120 / 133$ & $121 / 129$ \\
\hline WMC 25 & $122 / 136$ & $118 / 133$ & $126 / 137$ & $135 / 148$ & $140 / 153$ \\
\hline WMC 48 & $123 / 143$ & $130 / 145$ & $132 / 147$ & $120 / 135$ & $127 / 144$ \\
\hline WMC 50 & $94 / 105$ & $93 / 102$ & $121 / 128$ & $103 / 113$ & $108 / 108$ \\
\hline WMC 283 & $80 / 91$ & $80 / 92$ & $87 / 93$ & $88 / 98$ & $88 / 102$ \\
\hline Xgwm 11 & $218 / 234$ & $216 / 230$ & $204 / 218$ & $202 / 218$ & $208 / 224$ \\
\hline Xgwm 626 & $115 / 128$ & $91 / 105$ & $121 / 135$ & $125 / 136$ & $132 / 144$ \\
\hline
\end{tabular}

Table 5. Shows allele's size of the hard wheat population

\begin{tabular}{|c|c|c|c|c|c|}
\hline varieties & Noor & Azadi & $\begin{array}{c}\text { Tamoz } \\
\mathbf{2}\end{array}$ & $\begin{array}{c}\text { Sham } \\
\mathbf{4}\end{array}$ & $\begin{array}{c}\text { Adana } \\
\mathbf{9 9}\end{array}$ \\
\hline Noor & 0.000 & & & & \\
\hline Azadi & 0.694 & 0.000 & & & \\
\hline Tamoz2 & 0.660 & 0.688 & 0.000 & & \\
\hline Sham4 & 0.675 & 0.722 & 0.610 & 0.000 & \\
\hline $\begin{array}{c}\text { Adana } \\
99\end{array}$ & 0.675 & 0.670 & 0.639 & 0.650 & 0.000 \\
\hline
\end{tabular}

Table 6. Shows the genetic diversity in five hard wheat varieties based on 10 SSR markers

\begin{tabular}{|c|c|c|c|c|c|c|c|}
\hline Marker & $\begin{array}{c}\text { Allele } \\
\text { Frequency }\end{array}$ & $\begin{array}{c}\text { Genotype } \\
\text { Number }\end{array}$ & $\begin{array}{c}\text { Allele } \\
\text { Number }\end{array}$ & Availability & He & Но & PIC \\
\hline WMC17 & 0.30 & 5.00 & 6.00 & 1.00 & 0.80 & 0.40 & 0.77 \\
\hline WMC20 & 0.20 & 5.00 & 7.00 & 1.00 & 0.84 & 1.00 & 0.82 \\
\hline WMC21 & 0.40 & 4.00 & 4.00 & 1.00 & 0.72 & 0.00 & 0.67 \\
\hline WMC24 & 0.20 & 5.00 & 9.00 & 1.00 & 0.88 & 0.80 & 0.87 \\
\hline WMC25 & 0.10 & 5.00 & 10.00 & 1.00 & 0.90 & 1.00 & 0.89 \\
\hline WMC48 & 0.10 & 5.00 & 10.00 & 1.00 & 0.90 & 1.00 & 0.89 \\
\hline WMC50 & 0.20 & 5.00 & 9.00 & 1.00 & 0.88 & 0.80 & 0.87 \\
\hline WMC283 & 0.20 & 5.00 & 8.00 & 1.00 & 0.86 & 1.00 & 0.84 \\
\hline Xgwm11 & 0.30 & 5.00 & 8.00 & 1.00 & 0.84 & 1.00 & 0.82 \\
\hline Xgwm626 & 0.10 & 5.00 & 10.00 & 1.00 & 0.90 & 1.00 & 0.89 \\
\hline Mean & 0.21 & 4.90 & 8.10 & 1.00 & 0.85 & 0.80 & 0.83 \\
\hline
\end{tabular}

The value of the availability which is the number of observed alleles per number of individuals sampled was found to be high in all loci with an average of 1.0. This average indicated that there was no null allele sample in all loci. The expected heterozygosity's $(\mathrm{He})$ in this group of wheat ranged from 0.84 for WMC20 and Xgwm11 loci to 0.90 for WMC25, WMC48 and Xgwm626 loci with an average of 0.85 . The Ho value ranged from 0.4 for $\mathrm{WMC} 17$ locus to 1.0 for most of the other loci with an average of 0.66 . The polymorphic information content (PIC) values for overall genetic variability was also calculated for all primers (Tables 6). The highest PIC value of 0.89 was observed in and WMC25, WMC48 and Xgwm626 loci and the lowest value of 0.67 in WMC2 1 with an average of 0.83 for all loci.

3.2.1 Genetic relationships between hard wheat varieties: The calculated genetic distance for the hard wheat varieties is shown in Table 7 . The lowest genetic distance $(0.45)$ was found between Icrasha and Secondroue and the highest genetic distance with a value of 0.60 was found between Acsad and Icrasha as well between Acsad and Secondroue varieties. The overall average of genetic distance among these varieties is equal to 0.52 . Results of the phylogenic dendrogram based on a genetic analysis of distance matrix are shown in Figure 3. The dendrogram separated the five hard wheat varieties into two main groups. The first group consists of Icrasha, Berghouata and Secondroue varieties. The second group consists of Simeto and Acsad. The highest similarity value was observed between Icrasha and Secondroue varieties while the highest distance was between Acsad and Berghouata varieties. 


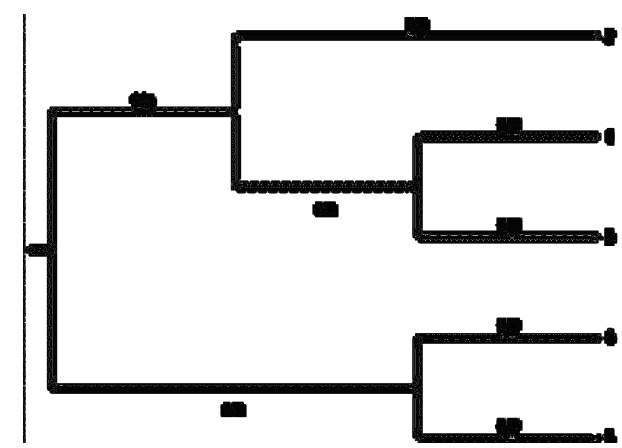

Figure 3. Dendrogram for five hard wheat varieties showing the genetic similarity derived from a UPGMA cluster analysis

Table 7. Genetic distance for the 5 hard wheat varieties based on 10 SSR microsatellite markers, the varieties are: 1-Icrasha 2-Berghouata 3-Secondroue 4-Simeto 5-Acsad

\begin{tabular}{|c|c|c|c|c|c|}
\hline Variety & Icrasha & $\begin{array}{c}\text { Bergh } \\
\text { ouata }\end{array}$ & $\begin{array}{c}\text { Secon } \\
\text { droue }\end{array}$ & Simeto & Acsad \\
\hline Icrasha & 0.000 & & & & \\
\hline $\begin{array}{c}\text { Bergh } \\
\text { ouata }\end{array}$ & 0.550 & 0.000 & & & \\
\hline $\begin{array}{c}\text { Secon } \\
\text { droue }\end{array}$ & 0.450 & 0.575 & 0.000 & & \\
\hline Simeto & 0.550 & 0.600 & 0.575 & 0.000 & \\
\hline Acsad & 0.600 & 0.575 & 0.600 & 0.575 & 0.000 \\
\hline
\end{tabular}

\subsection{Population structure analysis of both wheat species}

The genetic diversity in both wheat species is shown in Table 8. Allele frequency ranged from 0.10 to 0.30 with a mean of 0.17 . The total number of detected alleles was 140 and its average was 14.1. The largest number of 19 alleles was estimated for WMC24 locus, while the least score of seven was at WMC21 locus. The value of the availability was found to be high in all loci with an average of 0.98 . This average indicates that there were only a few null allele samples in all loci. The expected heterozygosity $(\mathrm{He})$ ranged from 0.82 in $\mathrm{WMC} 21$ to 0.95 in WMC25 locus with an average of 0.90 . The observed heterozygosity (Ho) ranged from 0.40 in $\mathrm{WMC} 17$ locus to 1.0 in Xgwm626 and Xgwm11 loci with an overall average of 0.73. The polymorphic information content (PIC) value for overall genetic variability was also calculated for all primers (Tables 8). The highest PIC value of 0.94 was observed for WMC24 locus and the lowest value of 0.84 indicated for WMC20 locus with an average of 0.90 for all loci.

Table 8. Shows the genetic diversity in 10 wheat varieties based on 10 SSR. Markers

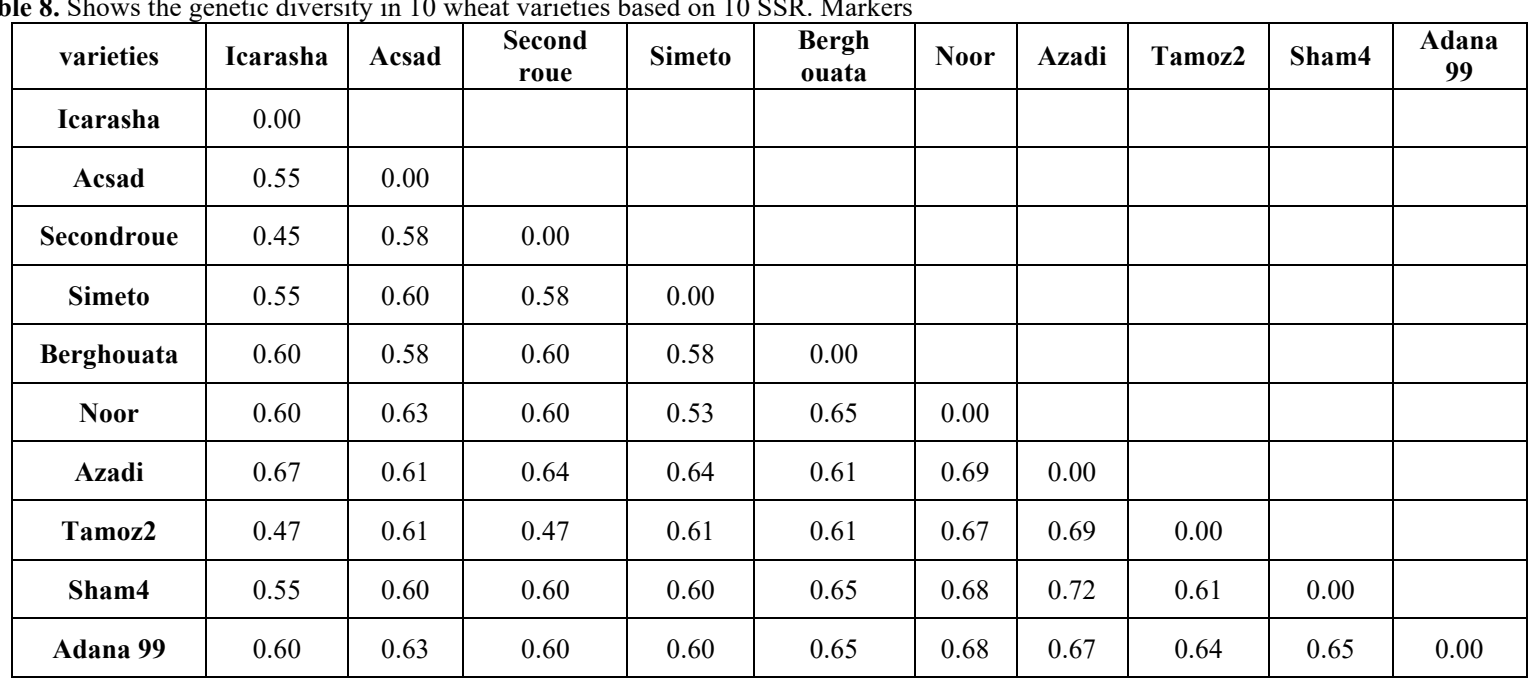

3.3.1 Genetic relationships between all wheat varieties: The calculated genetic distances for all 10 wheat varieties in both species are shown in Table 9. The lowest genetic distance (0.45) was found between Icrasha and Secondroue followed by 0.47 between Tamoz2 and Icarasha and Tamoz2 and Secondroue. The highest genetic distance with a value of 0.72 was found between Azadi and Sham4. The average genetic distance among all varieties was equal to 0.61 . The results of the phylogenic dendrogram based on a genetic analysis of distance matrix are shown in Figure 4. The first group consists of Icrasha, Berghouata and Secondroue varieties. The second group consists of Simeto and Acsad. The highest similarity value was observed between Icrasha and Secondroue varieties while the highest distance was between Acsad and Berghouata varieties. dendrogram discriminates the ten wheat varieties into five groups. The first group consists of Azadi variety, which is considered as simplicifolious and different from all other varieties. The second group consists of Adana99 variety, which also can be considered as a unique variety. The highest similarity value, which reflects small genetics distance, was observed between Icrasha and Secondroue varieties while the highest distance was between Azadi and Secondroue varieties. 
Table 9. Shows the genetic distance of the 10 wheat varieties based on 10 microsatellite alleles 1-Icarasha, 2-Acsad, 3-Secondroue, 4-Simeto, 5Berghouata, 6-Noor, 7-Azadi, 8-Tamoz2, 9-Sham4, 10- Adana 99

\begin{tabular}{|c|c|c|c|c|c|c|c|}
\hline Marker & $\begin{array}{c}\text { Allele } \\
\text { Frequency }\end{array}$ & $\begin{array}{c}\text { Genotype } \\
\text { Number }\end{array}$ & $\begin{array}{c}\text { Allele } \\
\text { Number }\end{array}$ & Availability & He & Ho & PIC \\
\hline WMC17 & 0.15 & 10.00 & 13.00 & 1.00 & 0.91 & 0.40 & 0.90 \\
\hline WMC20 & 0.28 & 8.00 & 10.00 & 0.90 & 0.85 & 0.89 & 0.84 \\
\hline WMC21 & 0.30 & 7.00 & 7.00 & 1.00 & 0.82 & 0.00 & 0.80 \\
\hline WMC24 & 0.10 & 10.00 & 19.00 & 1.00 & 0.95 & 0.90 & 0.94 \\
\hline WMC25 & 0.10 & 10.00 & 15.00 & 1.00 & 0.93 & 0.50 & 0.92 \\
\hline WMC48 & 0.10 & 9.00 & 16.00 & 1.00 & 0.93 & 0.90 & 0.93 \\
\hline WMC50 & 0.15 & 10.00 & 16.00 & 1.00 & 0.93 & 0.80 & 0.92 \\
\hline WMC283 & 0.20 & 10.00 & 12.00 & 1.00 & 0.90 & 0.90 & 0.89 \\
\hline Xgwm11 & 0.22 & 9.00 & 15.00 & 0.90 & 0.91 & 1.00 & 0.90 \\
\hline Xgwm626 & 0.10 & 10.00 & 17.00 & 1.00 & 0.94 & 1.00 & 0.93 \\
\hline Mean & $\mathbf{0 . 1 7}$ & $\mathbf{9 . 3 0}$ & $\mathbf{1 4 . 0 0}$ & $\mathbf{0 . 9 8}$ & $\mathbf{0 . 9 0}$ & $\mathbf{0 . 7 3}$ & $\mathbf{0 . 9 0}$ \\
\hline
\end{tabular}

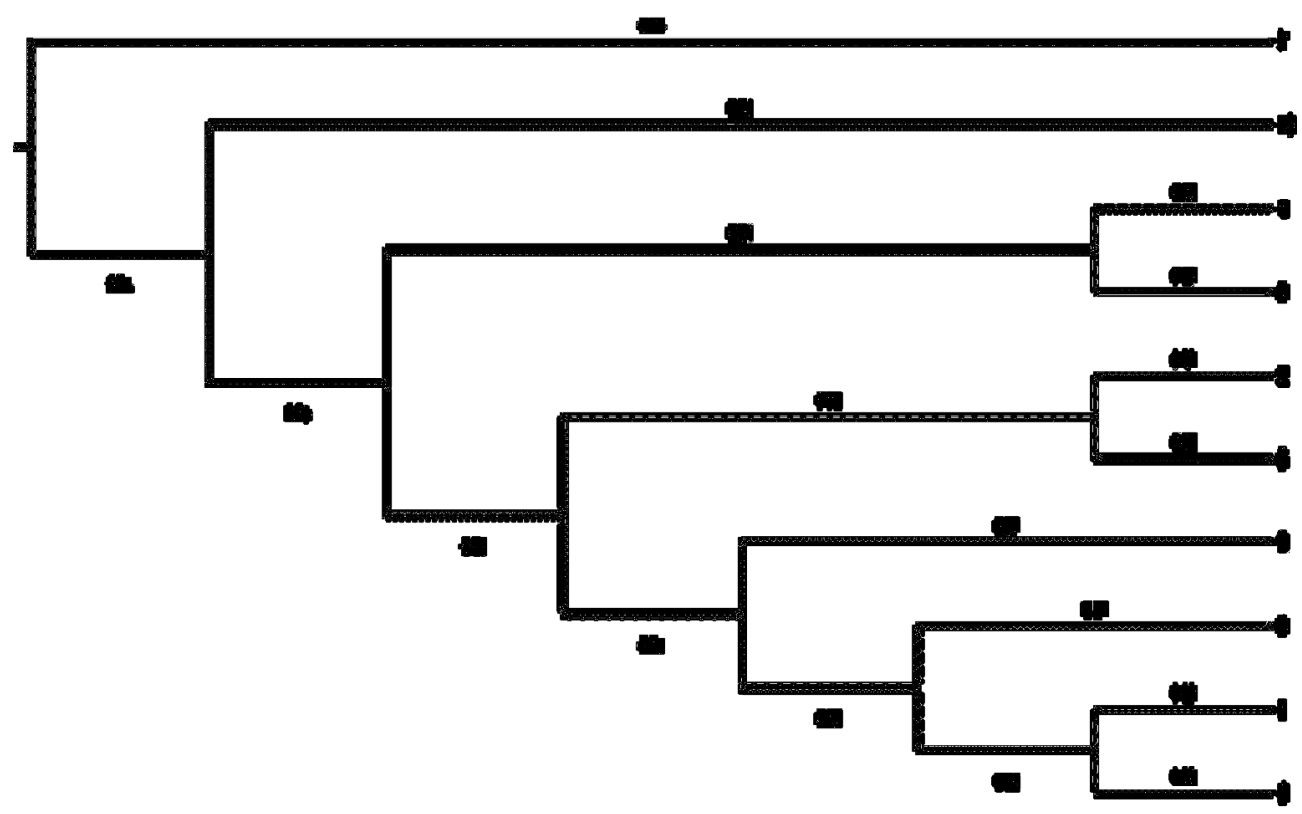

Figure 4. Dendrogram for 10 wheat varieties showing the genetic similarity derived from a UPGMA cluster analysis (1-5 hard wheat varieties 610 soft wheat varieties) 1-Icarasha, 2-Acsad, 3-Secondroue, 4-Simeto, 5-Berghouata, 6-Noor, 7-Azadi, 8-Tamoz 2, 9-Sham4, 10-Adana 99

\section{DISCUSSION}

Molecular markers have revolutionized and modernized our ability to characterize genetic variation and to rationalize genetic selection, being effective and reliable tools for the analysis of genome architectures and gene polymorphisms in crop plants (Barcaccia, 2010). Many studies have calculated genetic diversity and phylogenic relationships among wheat genotypes (Khan et al., 2015; Baloch et al., 2017). Similarly, various methods have been used for surveying population structures (Khan et al., 2014). Analysis of population structure is essential for collections, conservation, and sustainable utilization of gene bank accessions (Suresh et al. 2014). In both species, allele sizes detected by these primers ranged between 73 to $234 \mathrm{bp}$. Similar results were scored by Sönmezoğlu and Terzi (2018). The number of detecting alleles over all loci across the two populations ranged from 7 to 19 , with an average of 14 alleles per locus (Table 7). Roussel et al., (2004) used 42 SSR markers to analyze 559 French wheat accessions, reporting an average of 14.5 alleles per locus which is very close to the results of this study. Other studies in different wheat collections as well have reported averages close to these findings (Zhang et al., 2010; Hao et al., 2011; Bafghi et al., 2014; Salehi et al., 2018; Slim et al., 2019). Kara et al., (2016) reported an average of 3.2. A similar pattern of few alleles per locus was also detected by Babay et al., (2015). The high number of alleles per locus indicates a broad genetic base of these varieties. The major allele frequency which refers to how common an allele is in a population in the examined loci ranged between 0.19 in the soft wheat varieties to 0.21 in the hard wheat varieties with a great diversity between loci in both populations. Ya Narantsetseg et al., (2017) and Salehi et al., (2018) observed similar estimates. Gene diversity often referred to as expected heterozygosity $(\mathrm{He})$ which is considered as one of the common indicators in population genetics (Nei, 1987). The presence of a considerable level of genetic differentiation in populations is depicted by the value of gene diversity. The estimated $(\mathrm{He})$ value for the 10 varieties of both species was 0.85 which indicates a high degree of variations in both populations. This forms a good base for future wheat breeding program. The primers used in this study were able to discriminate between all the ten varieties. Similar variations have been reported by Salehi et al., (2018). The informativeness of SSRs was calculated using the polymorphism information content (PIC). The (PIC) values of the analyzed microsatellite markers, WMC24 locus had the highest PIC values followed by WMC48 and Xgwm626 primer and the lowest value of 0.84 was presented by WMC20 primer. These results suggest that all markers used in this study were highly informative; because the (PIC) values were higher than 
0.50 in all loci, therefore, they can be considered as useful markers for genetic diversity studies in wheat populations to be grown in this region and other places (Singh and Singh 2018). Genetic distance is a measure of the genetic divergence between species or within a species. This distance may measure time from a common ancestor or degree of differentiation (Nei, 1987). Populations with many similar alleles have small genetic distances. This indicates that they are closely related and have a recent common ancestor. Genetic distance is also used for understanding the origin of biodiversity. The microsatellites used in this study were efficient in discrimination between varieties within each species of soft and hard wheat rather than between the two species (Triticum aestivum L. and Triticum durum Desf.). The dendrogram in Figure 4 also demonstrates the ability of the microsatellites used in this study to detect significant quantities of genetic diversity in these wheat varieties. These data agree with the results of Kara et al., (2018).

The close genetic relationships observed between these two species can be explained by having common ancestor parents in their pedigree. For example, the close genetic relationship between durum wheat variety Icarasha and the soft wheat variety Tamoz. The dendrogram in Figure 4 divides the wheat varieties into two distinct groups: Azadi variety formed simplicifolious leave which is substantially different from all the other varieties. The superiority of Azadi variety for drought tolerance was also indicated by Ahmad et al. (2017), to screen common bread wheat varieties in Kurdistan, at germination and early growth stage.

\section{CONCLUSIONS}

In conclusion, 75 alleles were detected in soft wheat varieties and 81 alleles in hard wheat varieties. Allele frequency ranged from 0.10 to 0.30 . The observed heterozygosity (Ho) ranged from 0.40 to 1.0 while the expected heterozygosity $(\mathrm{He})$ revealed a high level of genetic diversity in tested varieties and ranged between 0.82 to 0.95 . The results of this study will provide information for future breeding programs and may be useful for the evaluation and conservation of wheat genetic resources.

\section{REFERENCES}

Ahmad Nariman S., Shadia H. S. Kareem, Kamil M. Mustafa and Dastan A. Ahmad (2017) Early Screening of Some Kurdistan Wheat (Triticum aestivum L.) Cultivars under Drought Stress. Journal of Agricultural Science; Vol. 9, No. 2. 88-103.

Allen, A. M., Winfield, M. O., Burridge, A.J., Downie, R. C., Benbow, H. R., Barker, G. L., Wilkinson, P.A., Coghill, J., Waterfall, C., Davassi, A. and Scopes, G. (2017). Characterization of a Wheat Breeders' Array suitable for high- throughput SNP genotyping of global accessions of hexaploid bread wheat (Triticum aestivum L.). Plant biotechnology journal, 15(3): 390-401.

Babay E., Chaabane R., Mzid-Abdmouleh R., Ben Naceur M. (2015). Diversity of Tunisian bread wheat genotypes revealed by Morpho-agronomical and microsatellite markers. Bioscience Journal, 31(3), 701-708.

Bafghi R. Mollaheydari, A. Baghizadeh, Gh. Mohammadi-Nejad, B. Nakhoda(2014) Assessment of genetic diversity in Iranian wheat (Triticum aestivum L.) cultivars and lines using microsatellite markers. Journal of Plant Molecular Breeding (JPMB). Vol. 2. no.1, 74-89.

Baloch Faheem Shehzad, Ahmad Alsaleh, Muhammad Qasim Shahid, Vahdettin Citi, Luis E. Sâenz de Miera, Muhammad Aasim, Muhammad Azhar Nadeem, Husnu Aktaş, Hakan Özkan, Rüștü Hatipoğlu (2017). A Whole Genome DArTseq and SNP Analysis for Genetic Diversity Assessment in Durum Wheat from Central Fertile Crescent. PLoS ONE12(1): e0167821.
Barcaccia Gianni (2010). Molecular Markers for Characterizing and Conserving Crop Plant Germplasm Chapter 10 S.M. Jain and D.S. Brar (eds.), Molecular Techniques in Crop Improvement. Springer Science +Business Media B.V. 2009

Bassam, Brant J \& Peter M Gresshoff (2007). Silver staining DNA in polyacrylamide gels nature protocols vol.2 No.11. 2649 .

Desheva, G. \& Kyosev, B. (2015). Genetic diversity assessment of common winter wheat (Triticum aestivum L.) genotypes. Emirates Journal of Food and Agriculture, 27(3), 283-290.

El-Fiki, A. \& Adly, M. (2019). Molecular characterization

and genetic diversity in some Egyptian wheat (Triticum aestivum L.) using microsatellite markers. Potravinarstvo Slovak Journal of Food Sciences, 13(1), 100-108.

Hao C., Wang L., Ge H., Dong Y. and Zhang X. (2011). Genetic diversity and linkage disequilibrium in Chinese bread wheat (Triticum aestivum L.) revealed by SSR markers. PLoS One $18 ; 6(2)$ e 17279.

Kara Karima, Najla Mezghani, Olfa Saddoud Debbabi, Maher Madini, Malika Rached-Kanouni1, M'barek Ben Naceur (2016). Assessment of genetic diversity of wheat (Triticum aestivum L.) using agro-morphological characters and microsatellite markers. International Journal of Biosciences vol. 9, No. 4, p. 92-101.

Kara, K., Kanouni, M. R., Debbabi, O. S., \& Naceur, M. B. (2017) Genetic diversity of bread wheat genotypes (Triticum aestivum L.) revealed by agromorphological characteristics and microsatellite SSR markers. Int J Res Eng Technol, 6 , 178-182.

Kara Karima, Rached-Kanouni Malika and Ben Naceur M'barek (2018). Investigation of Genetic Diversity among Bread Wheat Cultivars (Triticum aestivum L.) Using SSR Markers. 14th LISBON International Conference on Agricultural, Biological, Environmental and Medical Sciences (LABEMS-18) (Lisbon, Portugal) 17-19.

Kesawat, Mahipal Singh, and Basanta Das Kumar. (2009). Molecular Markers: It's Application in Crop Improvement. Journal of Crop Science and Biotechnology 12 (4):169-81.

Khan MK, Pandey A, Choudhary S, Hakki EE, Akkaya MS, Thomas G. 2014. From RFLP to DArT: molecular tools for wheat (Triticum spp.) diversity analysis. Genetic Resources and Crop Evolution 61: 1001-1032.

Khan Mohd Kamran, Anamika Pandey, George Thomas, Mahinur S. Akkaya, Seyit Ali Kayis, Yusuf Ozsensoy, Mehmet Hamurcu, Sait Gezgin, Ali Topal and Erdogan E. Hakki (2015). Genetic diversity and population structure of wheat in India and Turkey. AoB PLANTS: plv083-plv083.

Kumar, P., Yadava, R. K., Kumar, S., \& Kumar, P. (2016). Molecular diversity analysis in Wheat genotypes using SSR markers. Electronic Journal of Plant Breeding, 7(2), 464468.

Nei, Masotoshi (1973). Genetic distance between populations. The American Naturalist, 106 (949), 283-292.

Nei, Masotoshi (1987). Molecular evolutionary genetics. Columbia university press. New York. 512 pp.

Raj, R. Sandeep, Yama S. Vyas, Viral Kumar M. Baranda, Madhvi N. Joshi, Shradha Nand Tyagi, and Snehal B. Bagatharia (2017). Ascertaining narrow genetic base in commercial accessions of wheat commonly grown in Gujarat via molecular markers. Electronic Journal of Plant Breeding 8 (2): 558 .

Röder, M.S.; Korzun, V., Gill, B.S., Wendehake, K., Pleaschke, J., Tixier, M., Leroy, P., Ganal, M.W. (1998). A microsatellite map of wheat. Genetics 149: 2007-2023.

Roussel V, Koenig J, Beckert M, Balfourier F. (2004). Molecular diversity in French bread wheat accessions

related to temporal trends and breeding programmes. Theor. Appl. Genet. 108: 920-930.

Salehi, Marzeih, Ahmad Arzani, Majid Talebi and Asad Rokhzadi (2018). Genetic diversity of wheat wild relatives using SSR markers. Genetika, Vol. 50, No1, 131-141.

Salem, K. F., Röder, M. S., \& Börner, A. (2015). Assessing genetic diversity of Egyptian hexaploid wheat (Triticum aestivum L.) using microsatellite markers. Genetic resources and crop evolution, 62(3), 377-385.

Shewry, P. R. (2009). Wheat. Journal of experimental botany, 60 (6), 1537-1553. 
Singh Piyusha and Naveen Kumar Singh (2018). SSR Molecular Marker are efficient tools for finding

Genetic Diversity in Bread Wheat. International Journal of Current Microbiology and Applied SciencesSpecial Issue-7 pp. 1098-11053

Slim Amine, Luciana Piarulli, Houda Chennaoui Kourda, Mustapha Rouaissi, Cyrine Robbana, Ramzi Chaabane, Domenico Pignone, Cinzia Montemurro and Giacomo Mangini (2019). Genetic Structure Analysis of a Collection of Tunisian Durum Wheat Germplasm. Int.J.Mol.Sci. 20, 3362.

Sokal. R. R and C. D. Michener (1958). A statistical method for evaluating systematic relationships, Univ. Kans. Sci. Bull, 28, 1409-1438.

Sönmezoğlu Özlem Ates and Begüm Terzi1(2018). Characterization of some bread wheat genotypes using molecular markers for drought tolerance. Physiol Mol Biol Plants: 24(1):159-166.

Suresh S, Chung JW, Cho GT, Sung JS, Park JH, Gwag JG,

Baek HJ (2014). Analysis of molecular genetic diversity and population structure in Amaranthus germplasm using SSR markers. Plant Biosyst. 148: 635-644.
YaNarantsetseg, Sebastin Raveendar, Bayarsukh N, Myagmarsuren, Ya, Jung-Ro Lee, Kyung-Jun Lee, Myoung-Jae Shin, GyuTaek Cho, Kyung-Ho Ma, Gi-An Lee (2017) Genetic Diversity and Population Structure of Mongolian Wheat based on SSR Markers: Implications for Conservation and Management. Plant Breed. Biotech. 5(3):213 220.

Yadav, M. K., \& Chand, P. (2018). Assessment of Genetic Diversity among Twenty Indian Wheat (Triticum aestivum L.) Cultivars using Simple Sequence Repeat (SSR) Markers. Int. J. Curr. Microbiol. App. Sci, 7(3), 1708-1717.

Zarei Abbasabad E, Mohammadi SA, Moghaddam M, Jalal Kamali MR. (2016). Analysis of genetic diversity, population structure and linkage disequilibrium in Iranian wheat landraces using SSR markers. Plant Genetic Resources 1: 18 .

Zhang D, Bai G, Zhu C, Yu J, Carver BF. (2010). Genetic diversity, population structure, and linkage disequilibrium in U.S. elite winter wheat. The Plant Genome 3: 117-127. 